\author{
Бондарева Л.Л. - доктор с.-х. наук, зав. лаб. селекции и семеноводства капустных культур \\ Губкин В.Н. - кандидат с.-х. наук, С.н.с. лаб. селекции и семеноводства капустных культур \\ ФГБНУ «Всероссийский НИИ селекции и семеноводства овощных культур» \\ 143080, Россия, Московская обл., Одинцовский р-н, п. ВНИИССОК, ул. Селекционная, д. 14 \\ E-mail:vniissok@mail.ru
}

В статье описаны биологические особенности капусты савойской, подробно представлены агротехнические приемы ее вырачивания. Показаны основные направления селекции на современном этапе, дано краткое описание некоторых сортов и гибридов капусты савойской селекчии ВНИИССОК.

Ключевые слова: капуста савойская, биологические особенности выращивания, агротехнические приемы, селекция.

апуста савойская (Brassica oleracea

convar. capitata L. var. sabauda L.) получила своё название благодаря итальянской области Савойя, где ее выращивали с древних времен. В нашей стране является малораспространенной культурой, хотя в Европе пользуется устойчивым спросом благодаря отличным питательным свойствам и высокому содержанию витаминов. Особенно богата капуста савойская витаминами А (бета-каротином), В3, В6, В5, С (до 95 мг\%) и витамином Е. Она содержит около $10,5 \%$ сухого вещества, до 4,2\% сырого белка, $6 \%$ сахара, около 1,2\% клетчатки. Богата она горчичным маслом, фитонцидами и другими биологически активными веществами, минеральными солями натрия, калия, магния, кальция и фосфора. В савойской капусте содержится вещество, которое предотвращает развитие раковых опухолей и подавляет их рост (Пивоваров, 2006). По питательной ценности превосходит капусту белокочанную, подходит для диетического питания, т.к. имеет значительное количество белка и мало клетчатки. Ее рекомендуют при болезнях печени, сахарном диабете, гипертонии и атеросклерозе. Из капусты савойской готовят обладающие неповторимым вкусом голубцы, шницели, пироги, запеканки, салаты, солянку, овощные супы и прочее (Морозова, Пыльнева, 2007).

По внешнему виду капуста савойская похожа на белокочанную, однако листья ее имеют более насыщенный цвет и напоми- нают гофрированную бумагу. Благодаря этим нежным, пузырчатым, гофрированным листьям кочан неплотный. Он может быть округлым, овальным, конусовидным или плоским, а по окраске - зеленым, бледно-зеленым, беловато-кремовым и желтоватым. Восковой налет на листьях слабо выражен. Край листьев крупнозубчато-надрезанный. Такая надрезанность края листьев почти не встречается у капусты белокочанной. Наряду с кочанными формами у капусты савойской имеются и листовые, которые менее распространены (Лизгунова, Джохадзе, 1971; Лизгунова, 1984).

Капуста савойская - двулетнее растение. Растение формирует сидячие листья с короткими черешками. Кочан довольно крупный с короткой кочерыгой, в разрезе от бело-зеленого до желтого цвета. Встречается «розовидное» строение кочана: открытая сердцевина и большое количество кроющих листьев. Растения цветут и образуют семена на втором году жизни. Цветущие растения капусты савойской и белокочанной похожи, однако у капусты савойской лепестки цветков сильно гофрированные или пузыревидно-морщинистые. Семенники вступают в фазу массового цветения на 30-44-е сутки после высадки, созревание семян начинается на 55-65-е сутки после цветения. Плод - стручок длиной 7-8 см с четковидной поверхностью. Масса 1000 семян - 2-3 г. Урожайность семян - 300500 кг/га.
Капуста савойская отличается высокой холодостойкостью и морозостойкостью. Среднепоздние сорта первого года жизни выдерживают заморозки до $-5 \ldots-8^{\circ} \mathrm{C}$ в связи с повышенным содержанием сухого вещества в тканях растений. Требовательна к влажности почвы, однако легко переносит засушливые периоды вегетации. Наибольшая потребность в влаге наблюдается в период нарастания розетки листьев и образования кочана. Капуста савойская светолюбивое растение. Затенение и загущение посевов резко снижают урожайность и задерживают формирование продуктивных органов. Реакция почвенного раствора должна быть слабокислой (рН около 6,0). Меньше других видов капусты повреждается вредителями и болезнями. Требовательна к плодородию почвы и отзывчива на внесение органических и минеральных удобрений. Ранние сорта капусты савойской более скороспелы, чем сорта капусты белокочанной. Масса кочанов ранних сортов составляет 400-800 г, а кочаны поздних сортов достигают массы 2-3 кг. Вкус их улучшается от пониженных осенних температур, но по сравнению с поздними сортами капусты белокочанной они не выдерживают длительного хранения.

Учитывая высокую требовательность к содержанию питательных веществ в почве, капусту савойскую следуют размещать после внесения органических удобрений или по предшественникам, под которые они вносились. Капуста савой- 
ская хорошо отзывается на повышенные дозы калийных (при выращивании на торфяниках) и фосфорных (на тяжелых суглинистых почвах) удобрений. Получить более ранний урожай можно на плодородных легких и среднесуглинистых почвах, которые быстрее прогреваются. Лучшими предшественниками этой разновидности капусты являются бобовые овощные культуры, огурцы, лук, томат, картофель, свекла и многолетние бобовые травы. На прежнее место капусту можно возвращать не раньше, чем через 4-5 лет. В овощном севообороте капусту савойскую размещают первой культурой по органическому удобрению или после оборота пласта.

Система обработки почвы при выращивании капусты савойской включает осеннюю и весеннюю обработку, а также междурядное рыхление. Осеннюю подготовку почвы начинают с лущения поля, что вызывает частичное прорастание сорняков. Через 2-3 недели после лущения проводят зяблевую вспашку плугом с предплужником. Под зяблевую вспашку рекомендуется вносить 40-60 т/га органических удобрений.

Весной, чтобы не допустить пересыхания почвы, зябь боронуют. Легкую и богатую перегноем почву непосредственно перед посадкой рыхлят культиваторами на глубину 10-12 см и боронуют в два следа. На тяжелых почвах низинных участков проводят вспашку плугом.

В систему удобрений капусты савойской входят основное внесение и подкормки в период ухода. Основное внесение удобрений применяют осенью под зяблевую вспашку или весной под культивацию, добиваясь равномерного распределения удобрений по всему пахотному слою. Дозы основного минерального удобрения под капусту савойскую в среднем составляют для скороспелых сортов $\mathrm{N}_{75} \mathrm{P}_{50} \mathrm{~K}_{75}$; для среднеспелых и позднеспелых сортов - $\mathrm{N}_{100} \mathrm{P}_{65} \mathrm{~K}_{100}$.

Капусту савойскую в основном выращивают через рассаду. Оптимальные условия для получения качественной рассады создаются в пленочных теплицах. Наиболее продуктивным и экономичным способом является выращивание рассады капусты савойской в кассетах. Основой технологического процесса является ячеистая кассета с размером ячейки 50×50 мм, 32×32 мм. Возможно применение кассет с другими размерами. Ограниченный объем корневой системы сдерживает ростовые процессы подземной части, однако само молодое растение при этом быстрее проходит этапы онтогенеза, что в свою очередь сказывается на уменьшении сроков выращивания рассады. Для достижения данных преимуществ необходимо равномерное обеспечение молодых растений светом, влагой, теплом и питанием. Сроки посева на рассаду зависят от скороспелости сорта или гибрида. В Центральной зоне РФ раннеспелые сорта высевают в марте, средние и поздние сорта и гибриды - в апреле. Рассада бывает готова к высадке в фазе четырех-пяти настоящих листьев - в возрасте 35-45 суток. Скороспелые сорта высаживают в открытый грунт по схеме 60×40 или 70×35 см; средние и поздние - 70х50 или 70х60 см. При очень ранней посадке рассады в открытый грунт растения рекомендуется прикрывать защитным материалом, чтобы уберечь их от возможных низких температур.

Капуста савойская очень отзывчива на рыхление и подкормки. В течение вегетации обычно проводят до шести рыхлений, включая окучивание. При этом сухие и легкие почвы обрабатывают мельче, влажные и тяжелые - глубже. Очень важно своевременно провести первое рыхление на глубину 5-8 см. Его делают спустя 10-12 суток высадки рассады. Глубину последующих рыхлений увеличивают до 12-15 см. Но во избежание повреждения корней около растений проводят совсем мелкое рыхление. Растения ранних сортов и гибридов окучивают один раз, поздние - дважды. Первое окучивание проводят спустя 25-30 суток после высадки, второе - перед смыканием рядов. Своевременное и тщательное рыхление междурядий способствует более полному уничтожению сорняков. Благодаря этому ручное рыхление и прополку вокруг растений проводят лишь 1-2 раза.

В поливе растения капусты савойской раннеспелого срока созревания более всего нуждаются в мае, полив позднеспелых сртов необходим с начала июля до середины августа. Поливная норма составляет 350-400 мі/га за один полив до завязывания кочана и 400-450 мі/га после завязывания. Не рекомендуется поливать, если среднесуточная температура воздуха ниже $15^{\circ} \mathrm{C}$. Лучшее время для полива утренние и вечерние часы. В настоящее время наиболее распространенным способом является дождевание, которое позволяет равномерно распределять влагу по поверхности почвы, регулировать поливные нормы. Недостатком этого способа полива является опасность распространения болезней из-за испарения влаги с поверхности почвы. Более прогрессивным способом является капельное орошение. При этом поливе достигается наиболее равномерное распределение влаги для культурных растений. Вода доставляется непосредственно к корневой системе. Вместе с поливом имеется возможность проводить подкормку растений минеральными удобрениями с точным регулированием доз потребления.

Капусту савойскую, как и другие разновидности капусты, на протяжении всего вегетационного периода повреждают много вредителей: крестоцветные блошки, тля, капустные белянка и совка, капустная моль и трипсы и др. Поэтому в случае появления вредителей необходимо проводить систематические обработки инсектицидами. Из болезней наиболее вредоносными являются сосудистый и слизистый бактериозы, фузариозное увядание. В качестве мер борьбы рекомендуется использование устойчивых сортов, обеззараживание и протравливание семян, строгое соблюдение севооборота, поддержание высокого агротехнического фона.

Уборку капусты савойской производят при достижении ею хозяйственной годности, когда кочаны в зависимости от сорта приобретают бледно-зеленую или беловато-кремовую окраску. В Центральной зоне РФ раннеспелые сорта капусты савойской начинают выборочно убирать с конца июня, среднеспелые, среднепоздние и позднеспелые сорта убирают за один прием. Однако в более теплые и влажные годы во избежание растрескивания кочанов уборку проводят в два приема. Срезая кочаны, на них оставляют пару наружных листьев, благодаря которым внутренние листья будут предохранены от повреждения.

Пониженные осенние температуры благоприятно сказываются на савойской капусте позднеспелого срока созревания, повышая их вкусовые качества. Поэтому такие кочаны убирают, когда масса их достигает 2-3 кг. Кочаны поздних сортов в течение зимы можно хранить в хранилищах или подвалах, поддерживая температуру воздуха на уровне $1 . .3^{\circ} \mathrm{C}$ и относительную влажность - 90-95\%.

Еще в 30-е годы прошлого столетия на Грибовской опытной селекционной станции основатель отечественной селекции капустных культур Елена Михайловна Попова в свои исследования включила и капусту савойскую, исходным материалом которых служили сорта иностранной селекции и местные селекционные формы. Но в последнее время в соответствии с запросами рынка выдвигаются новые требования при создании сортов (гибридов) капусты савойской. Сорта (гибриды) капусты савойской должны составлять конвейер по группам спелости: от ультраскороспелых до позднеспелых, с возможностью хранения продукции до 
весны. Необходимыми показателями при создании сорта (гибрида) этой разновидности капусты являются содержание сухого вещества и пузырчатость листьев в сочетании с формой кочана от плоской до округлой (Бондарева, 2009).

В Государственный реестр селекционных достижений РФ на 2016 год включено 9 сортов и 11 гибридов F1 капусты савойской. Наиболее известны сорта селекции ВНИИССОК: скороспелый Юбилейная 2170 (период вегетации 102-114 суток) и среднепоздний Вертю 1340 (от всходов до хозяйственной годности 130-150 суток). В последние годы сортимент капусты савойской пополнился гибридами отечественной и иностранной селекции разных сроков созревания.

Во ВНИИССОК созданы сорта и гетерозисные гибриды капусты савойской от скороспелых до среднепоздних форм.

Юбилейная 2170 - скороспелый сорт, созревает через 65 суток после высадки рассады. Кочаны округлой или слегка овальной формы, средней плотности, массой 1 кг и более. Предназначены для раннего использования в свежем виде и в кулинарии. Урожайность до 40 т/га.

Елена F1 - среднеранний гетерозисный F1 гибрид, созревает через 100-105 суток после высадки рассады. Кочан округлой формы, крупный с хорошим сложением кроющих листьев, гофрированность - сильная, при средней пузырчатости, массой 1 кг. Урожайность 25 т/га. Отличительные признаки: интенсивно зеленая окраска кроющего листа с восковым налетом, продолжительный период хранения, высокие биохимические показатели качества кочана.

Вертю 1340 - среднепоздний сорт, созревает через 110 суток после высадки рассады. Предназначен для использования в осенний и осенне-зимний периоды. Кочаны округло-плоской формы, средней плотности, устойчивые к растрескиванию и средней лёжкости. Масса кочана от 1,2 до 2,5 кг. Урожайность достигает 50-70 т/га.
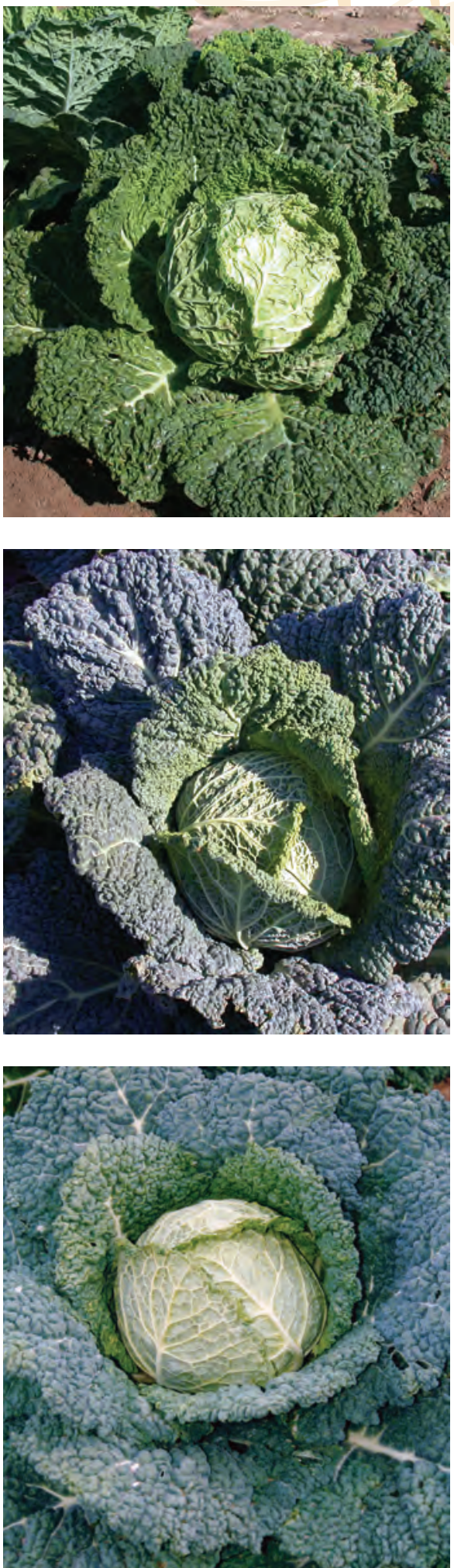

\section{SAVOY CABBAGE: \\ BIOLOGICAL AND \\ AGRO-TECHNICAL \\ FEATURES, \\ WAYS AND RESULTS \\ OF BREEDING}

Bondareva L.L., Gubkin V.N.

Federal State Budgetary Scientific Research Institution

"All-Russian Scientific Research

Institute of vegetable breeding and

seed production

143080, Russia, Moscow region,

Odintsovo district, p. VNIISSOK,

Selectionnaya street, 14

E-mail:vniissok@mail.ru

\section{Summary}

The biological properties and cultivation technology of savoy cabbage are presented in the article. The ways of breeding of this crop in VNIISSOK, some varieties and hybrids are described. Up to 2016, the 9 varieties and the 11 hybrids of savoy cabbage were included in to the State Register of selective breeding results (plant variety). The bestknown cultivars of VNIISSOK's breeding are the early maturing «Yubileynaya 2170» (vegetation season is 102-114 days) and the middle-late «Vertyu 1340» (130-150 days).

Keywords: savoy cabbage, biological properties, cultivation technology, breeding.

\section{Лumepamypa}

1. Бондарева Л.Л. Научное обоснование и разработка системы методов селекции и семеноводства капустных культур /Автореферат диссертации на соискание учёной степени доктора сельскохозяйственных наук. - М., 2009. - 48 с.

2. Лизгунова Т.В., Джохадзе Т.И. Капуста краснокочанная, савойская и брюссельская. /Л.: Отделение издательства «Колос». - 1971. - 89 с.

3. Лизгунова Т.В. Культурная флора СССР, том Х1. Капуста /Колос. - Л., 1984. - 328 с.

4. Морозова М.С., Пыльнева Е.В. Капуста: Пособие для садоводов-любителей /М.: Издательство «Никола-Пресс; Издательский дом «ЮНИОН-паблик». - 2007. - 192 с.

5. Пивоваров В.Ф. Овощи России /М., ВНИИССОК, 2006. - С.130-132. 